\title{
A STATEMENT OF POLICY
}

The editor of a scholarly journal, rather like a lion tamer, is in danger of being consumed by his work, and surely he will know at once whether he is doing his job badly or well. He has certain authority over his subjects; likewise they have power over him. Hence, understanding on both sides is imperative and ought to be arrived at as soon as possible. In case some old lions think they know already the rules of their trade, what follows is addressed to the younger ones who do not. And even old lions sometimes forget.

The most important fact about The Journal of British Studies' editorial policy has always been that it seeks articles from serious students in all fields concerned with British culture, politics, and history. But while remaining eclectic in scope, it must look for articles that are comprehensible to a wide range of readers. This means that an author should endeavor to explain at the beginning precisely what is important and new about his study and how it fits into the general context of his discipline. A good author tells in the first few paragraphs what the conventional wisdom about the topic is, in what way the author's discoveries depart from this, and why it is significant. In this way, the general reader knows what to look for within the narrative. The narrative itself presents only the evidence necessary to prove the point the author has already made and makes clear what is crucial and what is secondary. The conclusion should explain that the author has indeed shown what he said he would show at the beginning.

A good scholarly article, then, is not a short book, a mini-biography, or a report on research, still less a chapter from a longer work. It must be original in point of view or evidence and above all must contain its own reason for being. It does not follow that $J B S$ will never print articles of a polemic or bibliographic nature, but potential authors should be warned that the principal business of this journal is to keep its readers abreast of the most recent trends in interpretations and research in British studies.

A second point to be made, allied to the first, is that as a major journal with a large international circulation, which receives nearly a dozen submissions for every available space-a figure, by the way, which is growing $\longrightarrow J B S$ looks for articles of the widest possible interest. For instance, a single, newly discovered letter from a literary or historical figure, no matter how important the person, does not justify publication unless the document also provides the basis for some major revision in the interpretation of the person's career or works. There is a large and increasing number of specialized journals for which such studies are appropriate.

None of this is intended to discourage the submission of articles. While the Journal receives many more manuscripts than it can use, it does not receive many more good manuscripts than it needs, and its managers hope within the next year to expand its size. Anyone, therefore, with an idea, the evidence to back it up, a knowledge of English, and a typewriter is a possible author for JBS. He need not write first to ask whether we would be interested in the topic. We always are.

Bentley B. Gilbert 


\title{
THE JOURNAL OF BRITISH STUDIES
}

\author{
UNIVERSITY OF ILLINOIS \\ AT CHICAGO CIRCLE \\ CHICAGO, ILLINOIS
}

The Journal of British Studies, founded in 1961, is published at the University of Illinois at Chicago Circle under the auspices of the Conference on British Studies. It was the result of the imaginative generosity of a Trinity College alumnus, Frederick E. Hasler (Hon. LL.D. 1957) who contributed funds to the College for the specific purpose of establishing a learned periodical in the field of British history. Several Trinity alumni subsequently contributed to the fund. The University of Illinois at Chicago Circle now supports the publication of the Journal.

The Conference on British Studies is the official organization in the United States and Canada of scholars working in the field of British history and culture; its status as such is recognized by the American Historical Association, of which it is an affiliate. Its nearly 800 members are drawn from fifty states and five provinces. The national Conference convenes once each year, in the autumn, usually with one of the regional Conferences.

The Conference awards a prize every five years for the best first book by an American or Canadian scholar.

The Conference sponsors a considerable publications program. It publishes The Journal of British Studies at the University of Illinois at Chicago Circle; Archives in British History and Culture, a series devoted to the publication of documents, at West Virginia University, Morgantown; and Current Research in British Studies, a quadrennial survey of research in progress in the United States and Canada, published at Kansas State University, Manhattan, and edited at Western Washington State College. The Conference also sponsors a series of short monographs, Studies in British History and Culture, edited at Wittenberg University, Springfield, Ohio, and published by the Shoe-String Press, Hamden, Connecticut. Under the aegis of the Conference, Cambridge University Press continues to publish a bibliographical series. Albion prints the proceedings of the Conference in its regional and national meetings. Published four times a year at Appalachian State University, Boone, North Carolina, Albion is sent to all members of the Conference. The national Conference on British Studies has fostered the growth of a number of regional conferences: the Pacific Coast Conference, the Pacific Northwest Conference, the Rocky Mountain Conference, the Midwest Conference, the Southern Conference, the Mid-Mountain Conference, the Mid-Atlantic Conference, and the New England Conference. Each of these active and autonomous associations has its own officers, programs, and other activities.

The Journal of British Studies appears twice in the academic year, in the Fall and in the Spring. Inquiries about subscriptions should be directed to Bentley B. Gilbert, Editor, The Journal of British Studies, Department of History, University of Illinois at Chicago Circle, Box 4348, Chicago, Illinois 60680.

Manuscripts, not exceeding 8,000 words of text, should be sent also to Professor Bentley B. Gilbert at the same address. Please send two copies and a self-addressed return stamped envelope.

Volume XIX, No. 2 will be published in the Spring of 1980. 


\section{Slaves in Red Coats}

The British West India Regiments, 1795-1815

Roger Norman Buckley

The British West India Regiments, which fought in the Napoleonic Wars, were recruited from among Creole slaves and "raw" Africans in the Caribbean. This book examines the early history of these regiments within the context of the accelerating Africanization of British West Indian society, rebellions in the Caribbean, and British imperial expansion in Africa. $\$ 17.50$

\section{The Victorian Country House}

\section{Revised and enlarged edition}

Mark Girouard

Mark Girouard, author of the much-acclaimed Life in the English Country House, again displays his vast knowledge and critical insight in a revised and redesigned version of his now classic study of Victorian architecture. Girouard deals not only with the Victorian country houses themselves, but also with the architects involved, and the social, economic, and technological conditions that made such complex and often stunning structures possible. 420 black-and-white illus. +32 colorplates $\$ 29.95 \quad(\$ 35.00$ after Dec. 31)

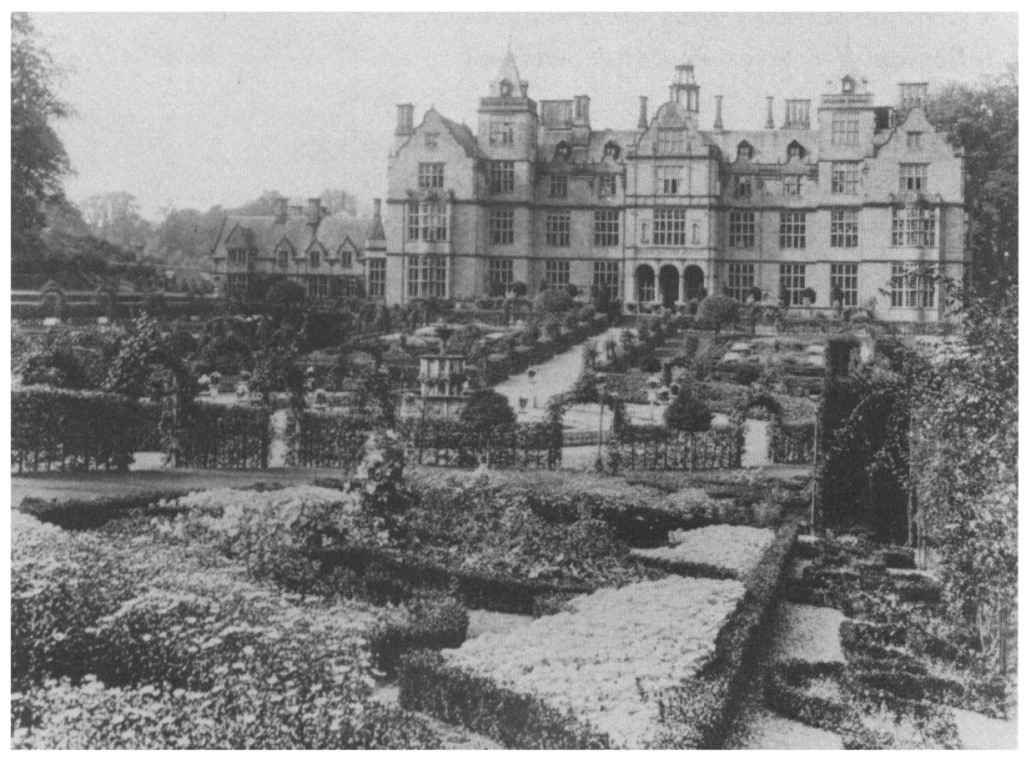

Yale University Press New Haven and London 


\title{
The William and Mary Quarterly
}

\author{
A Magazine of Early American History
}

\section{RECENT ARTICLES}

Commerce and Character: The Anglo-American

as New-Model Man

Ralph Lerner

The Radical Ideology of Samuel Gorton: New Light on the Relation of English to American Puritanism

Philip F. Gura

The Pro-Americans of London, 1769 to 1782

John Sainsbury

Redcoats in the Wilderness: British Officers and Irregular

Warfare in Europe and America, 1740 to 1760

Peter E. Russell

The Social Origins of Some Early Americans

An exchange between

David W. Galenson and Mildred Campbell

Jefferson and the Scottish Enlightenment:

A Critique of Garry Wills's Inventing America:

Jefferson's Declaration of Independence

Ronald Hamowy

\section{FORTHCOMING ARTICLES}

“A Man's House Is His Castle": British and American

Precedents Reconsidered

B. Carmon Hardy and William Cuddihy

George Grenville and America:

The Years of Opposition, 1765 to 1770

Philip Lawson

These articles appear or will appear shortly in The William and Mary Quarterly published by the Institute of Early American History and Culture. Yearly subscriptions, $\$ 10.00$, students $\$ 5.00$, single copies $\$ 3.00$. All communications should be addressed to the Editor, William and Mary Quarterly, Box 220, Williamsburg, Virginia 23185. 


\section{NOW AVAILABLE Observations from The Hague and Utrecht:}

William Henry Hamison's Letters to Henry Watkins, 1711-1712

Edited by

ISBN: 0-88215-042-1

Linda Frey

233 pp.; paperbound

Marsha Frey

John C. Rule

$\$ 14.95$ (20\% discount available to bookstores)

Prepaid orders sent postpaid

William Harrison was an enterprising young English journalist and protégé of Jonathan Swift. He served as queen's secretary to the British Embassy at The Hague from 1711 to 1713 . His candid views of the great and near-great in early eighteenth-century Europe are vividly expressed in his letters to his immediate superior. The editors provide the reader with an extensive introduction, notes, and an index to these ninety hitherto unpublished letters, which are part of The Ohio State University Libraries' Special Collections.

Order from the University Libraries Publications Committee Room 001 Main Library 1858 Neil Avenue Mall Columbus, Ohio 43210

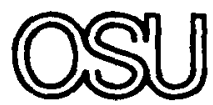
The Ohio State University

\section{THE CONFERENCE ON BRITISH STUDIES}

1979 BOOK PRIZE

has been awarded to

ANDREW ROSEN

for

Rise Up Women!

The Militant Campaign of the Women's Social and Political Union,

1903-1914

(Routledge and Keegan Paul, 1974)

The next award, limited to an author of a first published book in the field of British Studies, will be made in 1984. Persons who want to nominate books for consideration should communicate with the Executive Secretary of the Conference on British Studies. 


\section{British Socialists}

The Journey from Fantasy to Politics

Stanley Pierson

A new approach to the complex phenomenon of socialism, Pierson describes the growing dilemmas of the Socialists during the decisive period from 1900 to 1921 and examines the political and ideological disillusionment that attended the movement's disintegration. The study provides insight into British political institutions and into the development of the wider European Socialist movement in the twentieth century. $\$ 17.50$

\section{Crime and Conflict in English Communities, 1300-1348}

Barbara A. Hanawalt

Hanawalt investigates village and judi-. cial records of over 20,000 criminal court cases as well as coroners' and

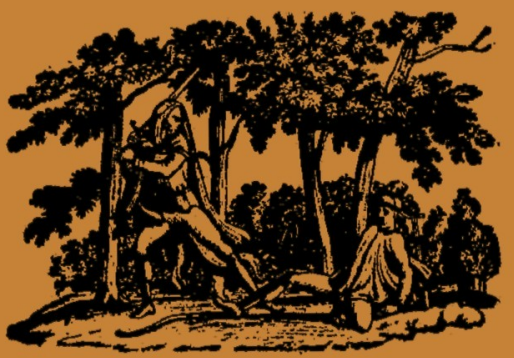
manorial court rolls in her insightful account of crime and conflict in Medieval England. The author's analyses of these data produce striking results; one interesting finding explodes the Robin Hood myth. $\$ 20.00$

\section{Sexuality and Feminism in Shelley}

Nathaniel Brown

This is an analysis of sexual attitudes and practices in the Romantic period, and a contribution to the history and theory of feminism. Brown compares Shelley with his contemporaries - particularly Byron - and explores the laws, ideas, and practices of the period. $\$ 17.50$

\section{Tennyson and Tradition}

Robert Pattison

"A genuinely new and exciting reading of Tennyson's poetry."

- E. D. H. Johnson

"We finish this brilliant book with an enhanced sense of how deeply Tennyson drew upon -yet how radically he transformed - the poetic past." -John Rosenberg $\$ 14.00$

\section{Harvard University Press}

Cambridge, Massachusetts 02138 


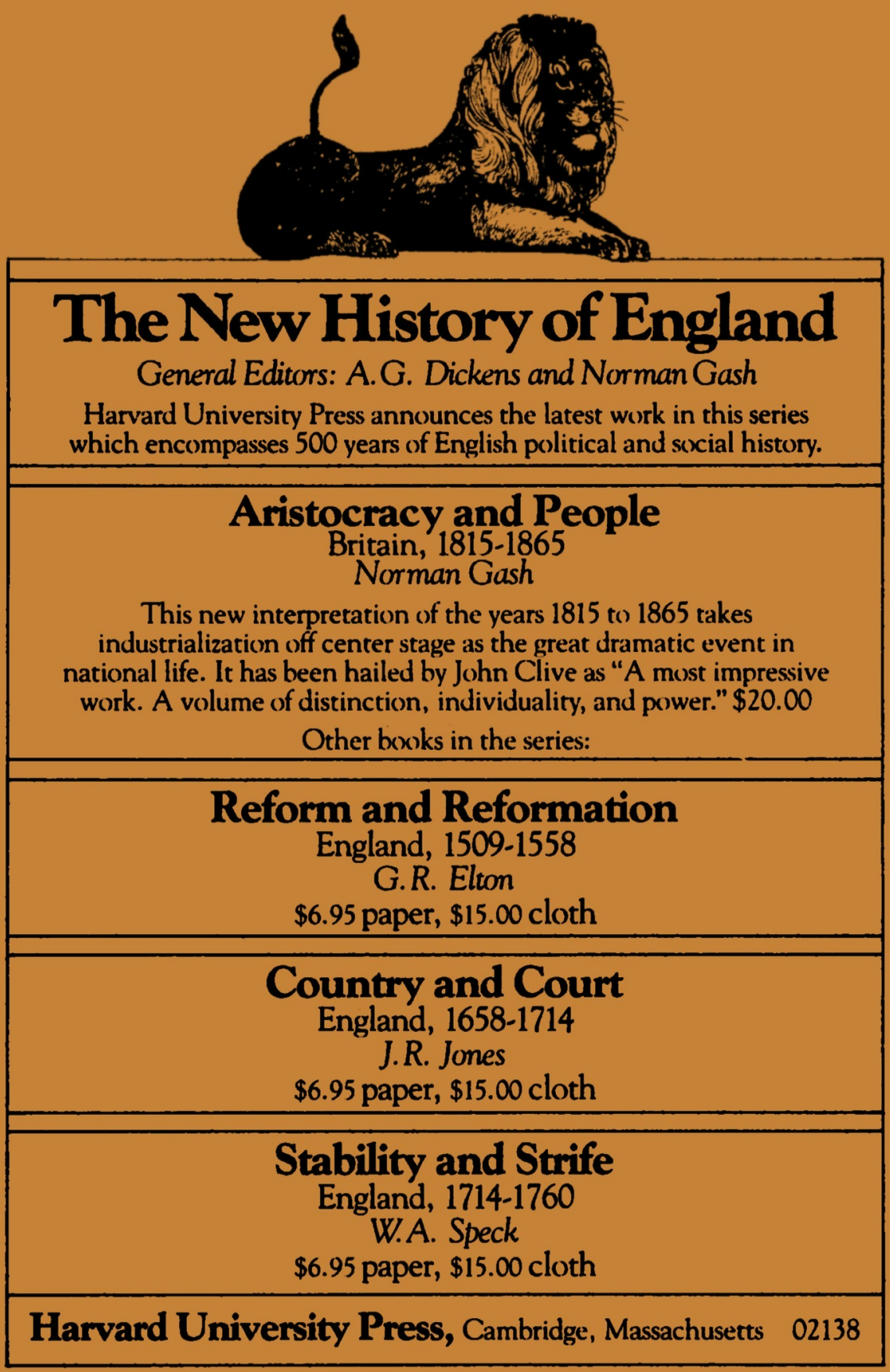

